\title{
STATUS KEBERLANJUTAN BUDIDAYA RUMPUT LAUT DI NEGERI SAWAI KECAMATAN SERAM UTARA KABUPATEN MALUKU TENGAH
}

\section{(The Sustainability Status of Seaweed in The Sawai Village, District of North Seram, Central Maluku Regency)}

\author{
Semuel F. Tuhumury ${ }^{1 *)}$, Miarah Bachmid ${ }^{2)}$ dan Masudin Sangaji ${ }^{3)}$ \\ ${ }^{1)}$ Jurusan Budidaya Perairan Fakultas Perikanan dan Ilmu Kelautan Universitas Pattimura \\ ${ }^{2)}$ Politeknik Negeri Masohi \\ ${ }^{3)}$ Jurusan Manajemen Sumberdaya Perairan Fakultas Perikanan dan Ilmu Kelautan Universitas Pattimura \\ *sf_tuhumury@unpattifpik.ac.id,m_bachmid@gmail.com,ms.unpatti@gmail.com \\ Corresponding author*
}

\begin{abstract}
ABSTRAK: Kegiatan budidaya rumput laut di Negeri Sawai, Kecamatan Seram Utara, Kabupaten Maluku Tengah telah dikenal sejak tahun 1994, namun belum terlihat perkembangan yang signifikan hingga sekarang. Untuk itu perlu dikaji status keberlanjutan budidaya rumput laut secara menyeluruh melalui lima dimensi yaitu dimensi ekologi, ekonomi, teknologi, sosial dan kelembagaan agar mendapatkan gambaran yang jelas mengenai kondisi budidaya rumput laut di Negeri Sawai. Penelitian ini bertujuan untuk mengetahui kondisi budidaya rumput laut di Negeri Sawai, menganalisis status dan indeks keberlanjutan kegiatan budidaya rumput laut dari lima dimensi keberlanjutan serta merumuskan arahan pengelolaan budidaya rumput laut di Negeri Sawai. Penelitian ini dilaksanakan pada bulan Desember 2016-Februari 2017 dengan menggunakan metode deskriptif kualitatif. Menggunakan data primer maupun sekunder. Hasil penelitian menunjukkan kondisi lingkungan perairan, serapan tenaga kerja, pemasaran, penanganan pasca panen, dan sistem pemeliharaan rumput laut di Negeri Sawai mendukung pengembangan rumput laut, sehingga berpeluang untuk dikembangkan sebagai sentral budidaya rumput laut potensial. Tingkat keberlanjutan budidaya rumput laut di Negeri Sawai, berada dalam kategori kurang berkelanjutan. Dimensi ekologi $(83,77 \%)$ berada pada status berkelanjutan, dimensi ekonomi $(47,81 \%)$ dimensi teknologi $(34,26 \%)$, dimensi sosial $(46,97 \%)$ dan dimensi kelembagaan $(32,84 \%)$ berada pada status kurang berkelanjutan. Terdapat delapan arahan pengelolaan yang dapat direkomendasikan untuk pengembangan budidaya rumput laut di Negeri Sawai.
\end{abstract}

Kata Kunci : Status keberlanjutan, budidaya, rumput laut, pengelolaan, Negeri Sawai

ABSTRACT: Seaweed cultivation activities in the Sawai Village, District of North Seram, Central Maluku Regency has been known since 1994, but has not seen a significant development until now. For it is necessary to study the sustainability status of seaweed cultivation as a whole through the five dimensions of the ecological, economic, technological, social and institutional in order to get a clear condition of seaweed cultivation. This study aims to determine the condition of seaweed cultivation in the Sawai Village, to analyze the status and sustainability indexes seaweed cultivation activities of the five dimensions of sustainability and to formulate the direction of the management of its seaweed cultivation. This research was conducted in December 2016February 2017 in Sawai Village. The method were used in this research is descriptive qualitative. The data were used a primary and a secondary data. The results showed that 
the condition of the aquatic environment, the emploiment, marketing, post-harvest handling, and which system maintenance seaweed in Sawai village supports the development of seaweed, so the opportunity to be developed as a central potential of seaweed farming. The level of sustainability of seaweed cultivation in the Sawai village, are in the category of less sustainable. ecological dimension $(83.77 \%)$ are in continuous status, the economic dimension $(47.81 \%)$ the technological dimension $(34.26 \%)$, the social dimension (46.97\%) and institutional dimension $(32.84 \%)$ are in status less sustainable. There are eight directions of management that could be recommended for the development of seaweed cultivation in the Sawai Village.

Keywords: Sustainability status, cultivation, seaweed, management, Sawai Village

\section{PENDAHULUAN}

Rumput laut merupakan salah satu komoditas utama perikanan budidaya yang bernilai ekonomis tinggi dengan peluang pasar yang luas, baik nasional maupun orientasi ekspor (Radiena, 2014; Damelia dan Soesilowati, 2016). Rumput laut dapat dibudidayakan secara masal sehingga menjadi salah satu komoditas strategis dalam program revitalisasi perikanan yang dicanangkan Kementerian Kelautan dan Perikanan (Setyaningsih $d k k ., 2011$ ). Program budidaya bertujuan untuk melindungi dan menjaga kelestarian sumberdaya serta memberikan manfaat bagi masyarakat untuk meningkatkan kesejahteraan (Mandika $d k k ., 2013$ ).

Dalam Rencana Tata Ruang wilayah Kabupaten Maluku Tengah tahun 2008-2028, Kecamatan Seram Utara masuk dalam Wilayah Pengelolaan II yang ditetapkan sebagai kawasan sentra perikanan budidaya dan tangkap. Negeri Sawai merupakan salah satu Negeri di pesisir utara Pulau Seram yang memiliki potensi perairan yang sangat besar untuk dikembangkannya usaha budidaya rumput laut (Maryunus $d k k$., 2018). Budidaya rumput laut mulai dikembangkan di Negeri Sawai pada tahun 1994 (DKP Malteng, 2014).

Secara umum produksi budidaya rumput laut Kabupaten Maluku Tengah mengalami penurunan yang sangat drastis mulai dari tahun 2010-2014. Produksi rumput laut di Kabupaten Maluku Tengah pada tahun 2010 yaitu sebesar 225 ton, namun pada tahun 2014 produksi rumput laut hanya mencapai 14,6 ton (DKP Malteng, 2014). Salah satu penyebab penurunan produksi rumput laut yaitu penurunan kualitas perairan sehingga menimbulkan penyakit pada rumput laut (Fitrian, 2015; Raharja dkk., 2016). Pemanfaatan sumberdaya pada suatu daerah ditujukan untuk mensejahterakan masyrarakat daerah tersebut. Potensi sumberdaya alam yang menjadi unggulan daerah baik di darat maupun laut dapat dikelola dengan tetap menjadi keberlanjutan sumberdaya tersebut. Luas perairan Maluku yang lebih besar dari luas daratan mendukung kegiatan budidaya terhadap sumberdaya rumput laut. Semestinya, penurunan produksi rumput laut yang telah disebutkan tidak akan terjadi jika berbagai aspek pendukung keberlanjutan sumberdaya rumput laut tersebut diketahui. Ditinjau dari aspek ekonomi yang secara langsung berhubungan dengan kesejahteraan masyarakat, rumput laut memberikan keuntungan juga bagi peningkatan pendapatan daerah. Berdasarkan uraian diatas, maka penelitian tentang status keberlanjutan budidaya rumput laut yang ditinjau dari dimensi ekologi, ekonomi, teknologi, sosial dan kelembagaan, menjadi sangat relevan untuk dilakukan di Negeri Sawai Kecamatan Seram Utara Kabupaten Maluku Tengah. Penelitian ini bertujuan untuk mengetahui kondisi budidaya rumput laut di Negeri Sawai, Kecamatan Seram Utara, Kabupaten Maluku Tengah, menganalisa status keberlanjutan budidaya rumput laut di Negeri Sawai, Kecamatan Seram Utara, Kabupaten Maluku Tengah ditinjau dari dimensi ekologi, teknologi, ekonomi, sosial dan kelembagaan dan merumuskan arahan pengelolaan budidaya rumput laut di Negeri Sawai, Kecamatan Seram Utara, Kabupaten Maluku Tengah. 


\section{METODE PENELITIAN}

Kegiatan penelitian ini dilakukan Negeri Sawai, Kecamatan Seram Utara, Kabupaten Maluku Tengah, pada bulan Desember 2016Februari 2017. Jenis data yang dikumpulkan dalam penelitian ini terdiri dari data primer dan data sekunder. Data primer adalah data yang diperoleh secara langsung melalui observasi dan wawancara langsung. Obeservasi dilakukan dengan mengambil data parameter lingkungan meliputi suhu, salinitas, $\mathrm{DO}, \mathrm{pH}$, kecepatan arus, kecerahan, dan substrat. Wawancara dilakukan dengan menggunakan kuesioner kepada pembudidaya rumput laut di Negeri Sawai serta stakeholder terkait.

Keberlanjutan kegiatan budidaya rumput laut dianalisis secara statistic multivariate dengan pendekatan Multidimensional Scaling (MDS). Analisis keberlanjutan kegiatan budidaya rumput laut ini ditujukan untuk mengetahui kemungkinan keberlanjutan kegiatan budidaya rumput laut untuk pemanfaatan yang optimal. Keberlanjutan kegiatan budidaya rumput laut dianalisis dengan mengunakan metode RAPFISH (Rapid Assessment Techniques for Fisheries). Analisis arahan pengelolaan dalam penelitian ini dilakukan dengan mengutamakan atribut-atribut yang sensitif untuk meningkatkan status keberlanjutan budidaya rumput laut di Negeri Sawai.

\section{HASIL DAN PEMBAHASAN}

Berdasarkan hasil pengukuran parameter fisik dan kimia perairan, suhu di lokasi penelitian cenderung tidak terlalu bervariasi dan layak bagi pertumbuhan rumput laut, karena lokasi penelitian merupakan perairan dangkal dengan kedalaman yang tidak terlalu berbeda. Lokasi penelitian yang berada jauh dari pemukiman penduduk, berdampak baik karena dapat terhindar dari pencemaran khususnya limbah rumah tangga ataupun industri yang dapat mempengaruhi parameter kualitas air. Kisaran suhu yang masuk kategori sangat sesuai untuk budidaya rumput laut yaitu $26{ }^{\circ} \mathrm{C}-31{ }^{\circ} \mathrm{C}$ (Sulma dan Manoppo, 2008; Risnawati $d k k .$, 2018) (Tabel 1). Salinitas di lokasi penelitian cenderung tidak terlalu bervariasi. Secara umum salinitas perairan di lokasi penelitian masih dalam kisaran yang menunjang pertumbuhan rumput laut yang dibudidayakan. Hasil pengukuran DO berkisar antara 4.17-6.07 mg/l yang menunjukan bahwa nilai tersebut masih layak untuk pertumbuhan rumput laut. Derajat keasaman $(\mathrm{pH})$ perairan juga memiliki peran yang cukup signifikan dalam pertumbuhan rumput laut. Hasil pengukuran diperoleh nilai $\mathrm{pH}$ berkisar antara 8.04-8.21. Arthana dkk. (2012), menyatakan bahwa $\mathrm{pH}$ yang baik dan sesuai untuk budidaya rumput laut berkisar antara 6-9.

Kecepatan arus perairan di lokasi penelitian termasuk dalam kategori kisaran yang sesuai untuk buidaya rumput laut. Kamlasi (2008) mendapatkan bahwa kecepatan arus yang baik untuk budidaya Eucheuma adalah 20-40 cm/detik. Adanya arus air yang baik dapat menjamin tersedianya nutrien yang tetap bagi rumput laut. Kondisi kecerahan perairan di lokasi penelitian yaitu $7 \mathrm{~m}$, dapat dikatakan tinggi ditunjukkan dengan kondisi terumbu karang yang masih bagus.

Tabel 1. Kondisi parameter fisik, kimia perairan pesisir Negeri Sawai

\begin{tabular}{|c|c|c|c|}
\hline No. & Parameter & Hasil & Kesesuaian \\
\hline 1. & Suhu Perairan & $29,3^{\circ} \mathrm{C}-30.7^{\circ} \mathrm{C}$ & Sangat Sesuai \\
\hline 2. & Salinitas Perairan & $32.83-33.16 \mathrm{ppt}$ & Sangat Sesuai \\
\hline 3. & DO & $4.17-6.07 \mathrm{mg} / 1$ & Sangat Sesuai \\
\hline 4. & $\mathrm{pH}$ & $8.04-8.21$ & Sangat Sesuai \\
\hline 5. & Kecepatan Arus & $20,4-23,11 \mathrm{~cm} /$ detik. & Sangat Sesuai \\
\hline 6. & Kecerahan Perairan & 7 meter & Sangat Sesuai \\
\hline 7. & Keterlindungan & Sangat terlindung & Sangat Sesuai \\
\hline 8. & Substrat & pasir dan patahan karang & Sangat Sesuai \\
\hline Kriteria kesesuai & $\begin{array}{l}\text { berdasarkan: Pratomo }(199 \\
\text { Ariati, } d k k(2007)\end{array}$ & $\begin{array}{lll}\text { arini } & (2003), & \text { Setiadi } \\
\text { ian Kamlasi (2008) }\end{array}$ & Sulma, et al \\
\hline
\end{tabular}


Kecerahan air memberikan petunjuk tentang daya tembus atau penetrasi cahaya ke dalam air laut, Kamlasi (2008) menyatakan bahwa kecerahan untuk budidaya rumput laut Euchema cottoni lebih besar dari $5 \mathrm{~m}$.

Letak areal budidaya di lokasi penelitian cukup strategis karena berada diantara Pulau Seram pada bagian selatan, Pulau Raja pada bagian barat laut dan Pulau Sawai pada bagian utara. Dengan demikian lokasi budidaya ini terlindungi dari hempasan ombak besar dan arus yang kuat pada saat musim timur. Perairan lokasi budidaya juga tidak digunakan sebagai jalur transportasi umum sehingga perairannya terbebas dari pencemaran. Mudeng $d k k$ (2015) menyatakan bahwa pasir yang tercampur patahan karang merupakan dasar perairan yang ideal sebagai lokasi budidaya rumput laut, hal ini sangat berhubungan dengan sediaan nutrien yang berguna bagi pertumbuhan rumput laut. Kondisi dasar perairan yang demikian merupakan petunjuk adanya gerakan air yang baik. Lokasi penelitian budidaya rumput laut ini memiliki substrat berupa pasir dan patahan karang. Dengan demikian dapat dikatakan bahwa substrat pada lokasi penelitian sangat mendukung untuk proses budidaya rumput laut.

Benih rumput laut yang digunakan oleh pembudidaya di Negeri Sawai awalnya didatangkan dari Pulau Osi, Seram Bagian Barat dengan harga $8000 / \mathrm{kg}$. Selanjutnya dalam proses pembudidayaan menggunakan bibit dari sisa panen. Rumput laut yang dibudidayakan adalah dari spesies Euchema cottoni. Berat bibit yang ditanam dalam tiap ikatan berkisar 50-100 gr dengan jarak tanam antar ikatan yaitu 20-25 cm serta penanaman dilakukan pada kedalaman 15-30 cm. Budidaya rawai atau longline dipilih oleh pembudidaya di lokasi penelitian ini karena pembuatan sarana budidayanya menggunakan bahan-bahan yang mudah didapat dengan biaya yang lebih murah dibandingkan metode rakit. Sistem budidaya di Negeri Sawai umumnya menggunakan sistem kelompok yang beranggotakan 5-8 orang. Dalam proses pengikatan bibit, pengontrolan atau pembersihan rumput laut saat ditanam, pemanenan dan penjemuran, tenaga kerja yang dilibatkan berasal dari anggota keluarga maupun masyarakat sekitar Negeri Sawai.

Secara umum kondisi rumput laut yang dibudidayakan di Negeri Sawai tampak baik karena faktor keterlindungan, perairan yang bersih dan penanganan secara berkala yang dilakukan, akan tetapi jika terjadi perubahan musim mengakibatkan rumput laut mengalami stress dan mudah terserang penyakit ice-ice. Permasalahan yang ditemui dalam usaha budidaya rumput laut di Negeri Sawai antara lain hama dan penyakit ice-ice. Penyakit ice-ice umumnya menyerang tanaman rumput laut pada saat musim peralihan dimana kualitas air di lokasi budidaya menurun (Erbabley dan Kelabora, 2018; Maryunus, 2018). Biota pengganggu (hama) merupakan salah satu hambatan dalam pengembangan budidaya rumput laut. Hama yang sering menyerang rumput laut dikelompokkan berdasarkan ukurannya yaitu hama mikro (micro graze) dan hama makro (macro grazer). Hama mikro umumnya berukuran kurang dari 2 $\mathrm{cm}$ dan melekat pada thallus tanaman seperti larva bulu babi dan larva teripang, sedangkan hama makro umumnya berukuran lebih dari 2 cm seperti ikan baronang (Siganus spp) dan penyu hijau (Chelonia midas) (Anggadireja et al, 2006). Hama yang sering menyerang rumput laut yang dibudidayakan di Negeri Sawai yaitu penyu dan ikan beronang.

Pengontrolan rumput laut dilakukan secara rutin setiap dua minggu sekali untuk mengangkat batang kayu atau sampah yang tersangkut di tali ris, serta membersihkan rumput laut dari kotoran yang menempel dengan cara menggoyangkan tali ris. Sampah organik berupa lamun yang telah mati dapat menjadi perantara pembawa kompetitor atau hama dari dasar perairan. Pembersihan sampah yang dilakukan dimaksudkan agar mengurangi beban pada tali agar tidak terputus.

Rumput laut yang telah dipanen kemudian akan dijemur atau dikeringkan. Pembudidaya memanfaatkan Pulau Sawai untuk membangun area pengeringan seluas 1 ha. Konstruksi tempat pengeringan rumput laut dibuat dari bambu dengan alas berupa waring/jaring hitam. Dalam proses pengeringan $7 \mathrm{~kg}$ rumput laut basah dapat menghasilkan 1 $\mathrm{kg}$ rumput laut kering. Rumput laut setelah dipanen kemudian dibersihkan dari kotoran 
yang menempel seperti pasir, lumut, dan lainlain untuk selanjutnya dilakukan proses penjemuran hingga benar-benar kering. Apabila cuaca bagus, penjemuran membutuhkan waktu 3 hari. Rumput laut yang telah kering akan mengeluarkan butir-butir garam yang berwarna putih kemudian rumput laut. Hasil panen rumput laut dari Negeri Sawai dipasarkan dalam bentuk rumput laut kering yang dikemas dalam karung-karung plastik untuk dijual ke pengumpul di Ambon. Selanjutnya menurut para responden, rumput laut kering yang dipasarkan ke Ambon akan dibawa ke Surabaya. Harga rumput laut kering yang dijual jika pasaran kurang stabil hanya $8000 / \mathrm{kg}$, namun jika permintaan tinggi harga rumput laut dapat mencapai $20.000 / \mathrm{kg}$.

Berdasarkan hasil analisis rapfish, diperoleh nilai indeks keberlanjutan dimensi ekologi adalah sebesar $83,77 \%$ dari skala berkelanjutan $0 \%$ (buruk) sampai dengan $100 \%$ (baik). Berdasarkan kategori indeks keberlanjutan (Kavanagh and Pitcher, 2004), maka kondisi dimensi ekologi berada pada kategori berkelanjutan. Nilai stress yang diperoleh untuk dimensi ekologi adalah sebesar $13,42 \%$. Nilai stress ini menggambarkan goodness of fit dimana nilai stress yang rendah menunjukan good fit sementara nilai stress yang tinggi menunjukan kondisi sebaliknya. Dalam analisis rapfish, model yang baik ditunjukan dengan nilai stress yang lebih kecil dari 0,25 (S < 25\%) (Fauzi dan Anna, 2002). Dengan demikian, analisis dimensi ekologi dalam penelitian ini menunjukan kondisi goodness of fit mengingat nilai stress yang diperoleh adalah kurang dari 25\%. Nilai kuadrat korelasi $\left(\mathrm{R}^{2}\right)$ yang diperoleh adalah sebesar $95,15 \%$.

Grafik Monte Carlo untuk dimensi ekologi menunjukan pencaran plot berada pada jarak yang relatif dekat satu sama lain (cenderung mengelompok) dan berhimpitan dengan posisi ordinasi indeks berkelanjutan dimensi ekologi. Dengan demikian, hasil analisis untuk menilai status keberlanjutan budidaya rumput laut memiliki tingkat gangguan yang kecil dan relatif stabil. Hasil analisis leverage (sensitifitas) terhadap seluruh atribut pada dimensi ekologi menunjukan bahwa atribut ketersediaan bibit rumput laut merupakan atribut yang cukup sensitif terhadap nilai indeks keberlanjutan dimensi ekologi. Hal ini dapat dinilai dari nilai root mean square change (rms) pada atribut ini yang lebih tinggi jika dibandingkan dengan atribut-atribut lainnya, yaitu sebesar 4,21. (Gambar 1). Dengan demikian, jika dilakukan perbaikan terhadap kualitas atribut ini maka akan meningkatkan nilai indeks keberlanjutan dimensi ekologi secara keseluruhan.

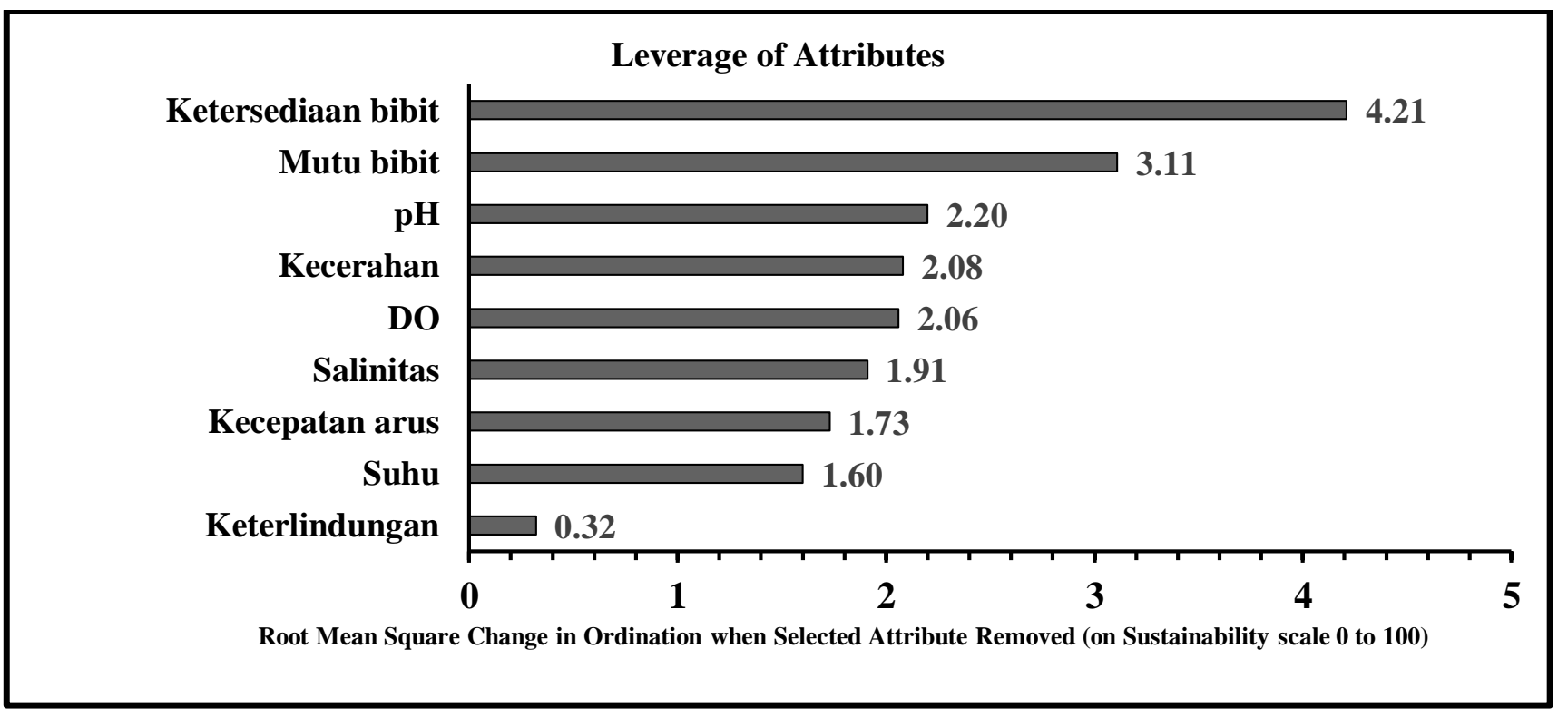

Gambar 1. Hasil analisis leverage dimensi ekologi 
Atribut ketersediaan bibit rumput laut merupakan atribut yang cukup berpengaruh terhadap keberlanjutan budidaya rumput laut di Negeri Sawai. Selama ini bibit yang digunakan untuk budidaya berasal dari bantuan pemerintah maupun bibit sisa hasil panen sebelumnya, oleh karena itu peran pemerintah sangat diperlukan guna meningkatkan kemandirian pembudidaya untuk memiliki kebun bibit rumput laut sehingga dapat menjaga ketersediaan bibit rumput laut secara kontinyu di Negeri Sawai. Dengan terjaminnya ketersediaan bibit rumput laut secara kontinyu melalui kebun bibit maka dapat meningkatkan nilai indeks keberlanjutan dimensi ekologi.

Nilai indeks keberlanjutan dimensi ekonomi yang diperoleh sebesar $47,81 \%$ dari skala berkelanjutan 0\% (buruk) sampai dengan 100\% (baik), sehingga dapat dikatakan bahwa kondisi dimensi ekonomi berada pada kategori kurang berkelanjutan. Kondisi ini perlu mendapatkan perhatian serius dalam pengelolaan untuk memperbaiki status keberlanjutan. Nilai stress yang diperoleh untuk dimensi ekonomi adalah sebesar 14,90\%. Dalam analisis rapfish, model yang baik ditunjukan dengan nilai stress yang lebih kecil dari 0,25 (s < 25\%) (Fauzi dan Anna, 2002). Dengan demikian, analisis dimensi ekonomi dalam penelitian ini menunjukan kondisi goodness of fit mengingat nilai stress yang diperoleh adalah $<25 \%$. Nilai kuadrat korelasi $\left(\mathrm{R}^{2}\right)$ yang diperoleh adalah sebesar 94,21\% .

Grafik Monte Carlo untuk dimensi ekonomi menunjukan pencaran plot berada pada jarak yang relatif dekat satu sama lain (cenderung mengelompok) dan berhimpitan dengan posisi ordinasi indeks berkelanjutan dimensi ekonomi. Dengan demikian, hasil analisis untuk menilai status keberlanjutan budidaya rumput laut memiliki tingkat gangguan yang kecil dan relatif stabil. Hasil analisis leverage (sensitifitas) terhadap seluruh atribut pada dimensi ekonomi menunjukan bahwa atribut kontibusi terhadap pendapatan asli daerah (PAD) merupakan atribut yang cukup sensitif terhadap nilai indeks keberlanjutan dimensi ekonomi. Hal ini dapat dinilai dari nilai root mean square change (rms) pada atribut ini yang lebih tinggi jika dibandingkan dengan atribut-atribut lainnya, yaitu sebesar 3,96 (Gambar 2). Dengan demikian, jika dilakukan perbaikan terhadap kualitas atribut ini maka akan mengungkit nilai indeks keberlanjutan dimensi ekonomi secara keseluruhan. Kontribusi kegiatan budidaya rumput laut terhadap Pendapatan Asli Daerah Kabupaten Maluku Tengah sampai saat ini tidak ada, karena tidak adanya iuran yang dibebankan kepada pembudidaya atas lahan yang digunakan.

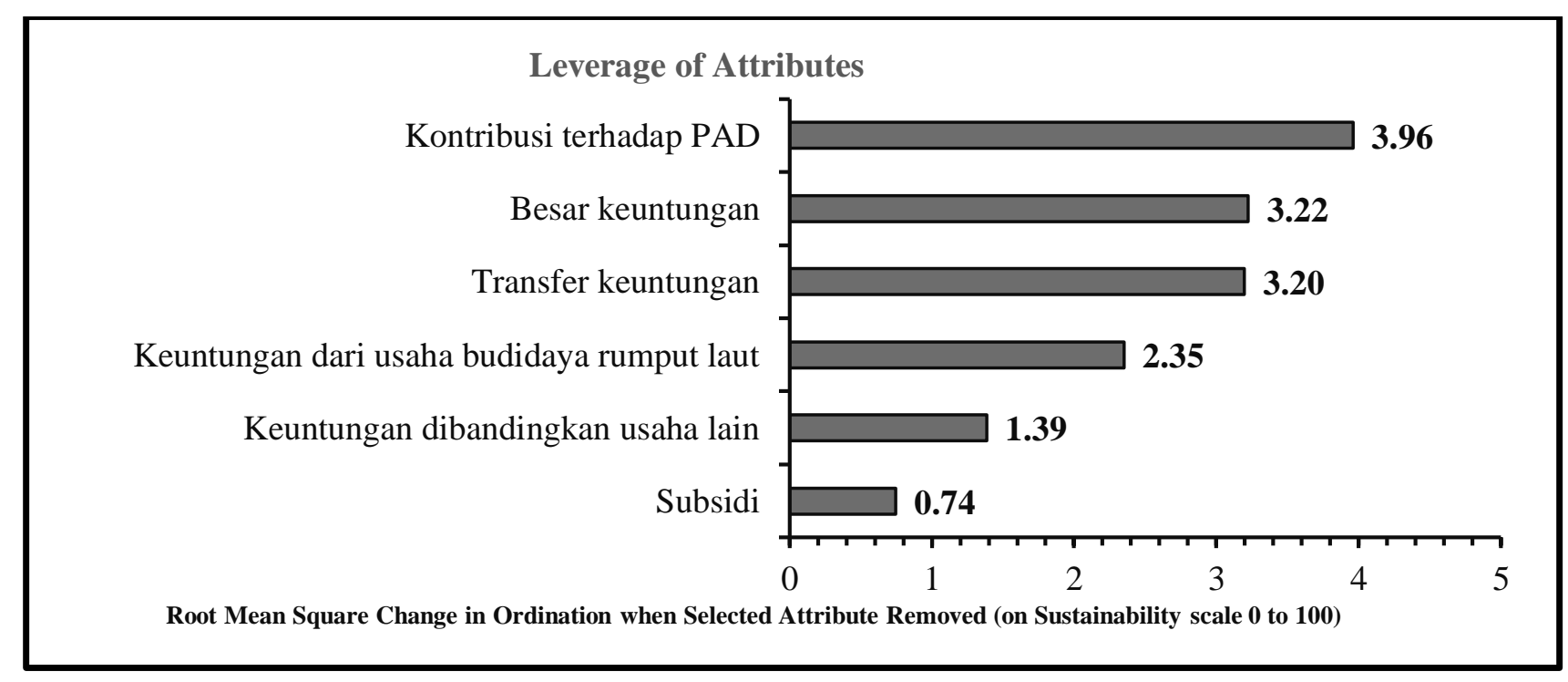

Gambar 2. Hasil analisis leverage dimensi ekonomi 
Nilai indeks keberlanjutan dimensi teknologi adalah sebesar $34,26 \%$ dari skala berkelanjutan $0 \%$ (buruk) sampai dengan $100 \%$ (baik). Berdasarkan kategori indeks keberlanjutan menurut Kavanagh and Pitcher (2004) maka kondisi dimensi teknologi berada pada kategori kurang berkelanjutan. Nilai stress yang diperoleh untuk dimensi teknologi adalah sebesar 13,33 \%. Dengan demikian, analisis dimensi teknologi dalam penelitian ini menunjukan kondisi goodness of fit mengingat nilai stress yang diperoleh adalah kurang dari 25\% (Fauzi \& Anna, 2002). Nilai kuadrat korelasi $\left(\mathrm{R}^{2}\right)$ yang diperoleh adalah sebesar $94,85 \%$.

Grafik Monte Carlo untuk dimensi teknologi menunjukan pencaran plot berada pada jarak yang relatif dekat satu sama lain (cenderung mengelompok) dan berhimpitan dengan posisi ordinasi indeks berkelanjutan dimensi teknologi. Dengan demikian, hasil analisis untuk menilai status keberlanjutan budidaya rumput laut memiliki tingkat gangguan yang kecil dan relatif stabil. Hasil analisis leverage (sensitifitas) terhadap seluruh atribut pada dimensi teknologi menunjukan bahwa atribut ketersediaan teknologi informasi merupakan atribut yang cukup sensitif terhadap nilai indeks keberlanjutan dimensi teknologi. Hal ini dapat dinilai dari nilai root mean square change (rms) pada atribut ini yang lebih tinggi jika dibandingkan dengan atribut-atribut lainnya, yaitu sebesar 6,51, namun atribut lain seperti tingkat penguasaan teknologi budidaya, ketersediaan teknologi informasi, dan ketersediaan industri rumput laut juga memiliki nilai root mean square change yang juga cukup tinggi (Gambar 3). Dengan demikian, jika dilakukan perbaikan terhadap kualitas atributatribut ini maka akan mengungkit nilai indeks keberlanjutan dimensi teknologisecara keseluruhan.

Atribut yang paling sensitif pada dimensi teknologi adalah ketersedian teknologi informasi dan ketersediaan industri rumput laut. Untuk itu sangat diperlukan peran pemerintah dalam rangka meningkatkan pengetahuan dan keterampilan pembudidaya agar masyarakat Negeri Sawai dapat memaksimalkan potensi lahannya. Atribut lainnya yang cukup sensitif pada dimensi teknologi yaitu standarisasi mutu rumput laut. Peran pemerintah dalam hal ini Dinas Kelautan dan Perikanan (DKP) melalui penyuluh perikanan harus mensosialisasikan standarisasi mutu rumput laut, karena selama ini para pembudidaya tidak mengetahui dengan pasti perbedaan penampilan fisik rumput laut yang bermutu baik atau bermutu jelek dalam kandungan karaginan dan kadar air.

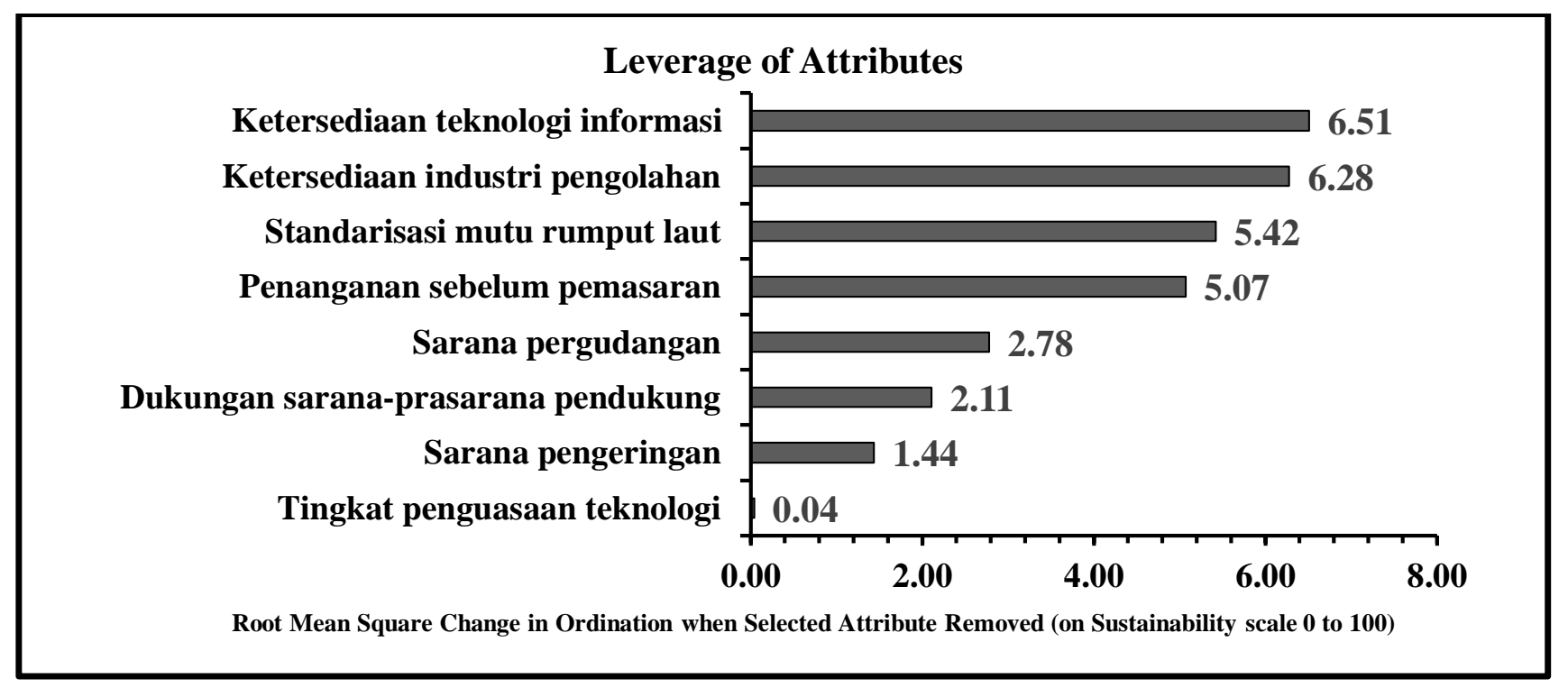

Gambar 3. Hasil analisis leverage dimensi teknologi 
Nilai indeks keberlanjutan dimensi sosial adalah sebesar $46,97 \%$ dari skala berkelanjutan $0 \%$ (buruk) sampai dengan $100 \%$ (baik), maka kondisi dimensi sosial berada pada kategori kurang berkelanjutan (Kavanagh and Pitcher, 2004). Nilai stress yang diperoleh untuk dimensi sosial adalah sebesar 14,51\%. Dengan demikian, analisis dimensi sosial dalam penelitian ini menunjukan kondisi goodness of fit mengingat nilai stress yang diperoleh adalah kurang dari 25\% (Fauzi dan Anna, 2002). Nilai kuadrat korelasi $\left(\mathrm{R}^{2}\right)$ yang diperoleh adalah sebesar $94,94 \%$.

Grafik Monte Carlo untuk dimensi sosial menunjukan pencaran plotberada pada jarak yang relatif dekat satu sama lain (cenderung mengelompok) dan berhimpitan dengan posisi ordinasi indeks berkelanjutan dimensi sosial. Dengan demikian, hasil analisis untuk menilai status keberlanjutan budidaya rumput laut memiliki tingkat gangguan yang kecil dan relatif stabil. Hasil analisis leverage (sensitifitas) terhadap seluruh atribut pada dimensi sosial menunjukan bahwa atribut potensi konflik dalam pengelolaan merupakan atribut yang cukup sensitif terhadap nilai indeks keberlanjutan dimensi sosial. Hal ini dapat dinilai dari nilai root mean square change (rms) pada atribut ini yang lebih tinggi jika dibandingkan dengan atribut-atribut lainnya, yaitu sebesar 3,49 (Gambar 4). Dengan demikian, jika dilakukan perbaikan terhadap kualitas atribut-atribut ini maka akan meningkatkan nilai indeks keberlanjutan dimensi sosial secara keseluruhan.

Potensi konflik akibat tidak tersedianya aturan yang mengatur pemanfaatan lahan budidaya rumput laut sangatlah besar. Peran pemerintah sangat dibutuhkan untuk mengatur tata kelola penggunaan lahan budidaya rumput laut di Negeri Sawai agar tidak terjadi konflik di kemudian hari. Perairan laut merupakan common property yang dapat dimanfaatkan oleh siapa saja, dengan melihat komoditi rumput laut yang semakin diminati oleh masyarakat karena memiliki nilai ekonomis yang tinggi, maka peran kelembagaan sangat dibutuhkan untuk menjadi wadah atau pengatur dalam meminimalisir potensi konflik.

Nilai indeks keberlanjutan dimensi kelembagaan adalah sebesar 32,84\% dari skala berkelanjutan $0 \%$ (buruk) sampai dengan $100 \%$ (baik), maka dapat dikatakan kondisi dimensi kelembagaan berada pada kategori kurang berkelanjutan (Kavanagh and Pitcher, 2004). Nilai stress yang diperoleh untuk dimensi kelembagaan adalah sebesar 13,45 \%. Dengan demikian, analisis dimensi kelembagaan dalam penelitian ini menunjukan kondisi goodness of fit mengingat nilai stress yang diperoleh adalah kurang dari 25\% (Fauzi dan Anna, 2002). Nilai kuadrat korelasi $\left(\mathrm{R}^{2}\right)$ yang diperoleh adalah sebesar $94,67 \%$.

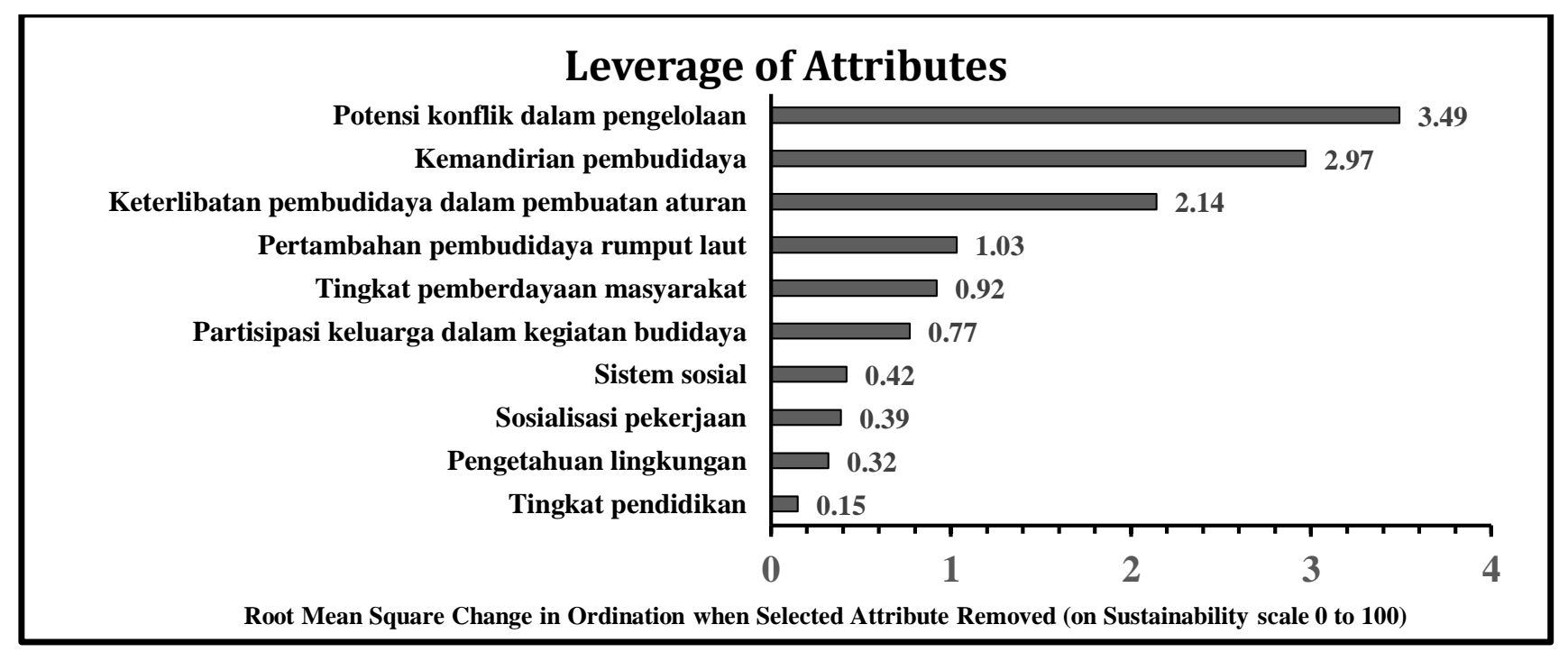

Gambar 4. Hasil analisis leverage dimensi sosial 
Grafik Monte Carlo untuk dimensi kelembagaan menunjukan pencaran plot berada pada jarak yang relatif dekat satu sama lain (cenderung mengelompok) dan berhimpitan dengan posisi ordinasi indeks berkelanjutan dimensi kelembagaan. Dengan demikian, hasil analisis untuk menilai status keberlanjutan budidaya rumput laut memiliki tingkat gangguan yang kecil dan relatif stabil.

Hasil analisis leverage (sensitifitas) terhadap seluruh atribut pada dimensi kelembagaan menunjukan bahwa atribut ketersediaan peraturan daerah merupakan atribut yang cukup sensitif terhadap nilai indeks keberlanjutan dimensi kelembagaan. Hal ini dapat dinilai dari nilai root mean square change (rms) pada atribut ini yang lebih tinggi jika dibandingkan dengan atribut-atribut lainnya, yaitu sebesar 5,25 (Gambar 5). Dengan demikian, jika dilakukan perbaikan terhadap kualitas atribut-atribut ini maka akan mengungkit nilai indeks keberlanjutan dimensi kelembagaan secara keseluruhan. Keberlanjutan usaha budidaya rumput laut harus didukung dengan tersedianya aturanaturan yang mengatur dengan jelas tentang pengelolaan, termasuk didalamnya lembaga- lembaga keuangan yang dapat digunakan oleh para pembudidaya untuk meningkatkan usaha budidaya rumput laut di Negeri Sawai. Secara khusus, belum terpdat peraturan daerah di Kabupaten Maluku Tengah yang mengatur tentang kegiatan budidaya rumput laut. Aturanaturan ini diperlukan agar kedepannya kegiatan budidaya rumput laut dapat berkembang dan berkelanjutan tanpa menimbulkan konflik yang merugikan bukan hanya bagi masyarakat pembudidaya rumput laut tetapi juga masyarakat luas pada umumnya, serta pemerintah secara keseluruhan. Peran penyuluh dan balai penyuluhan harus dioptimalkan untuk meningkatkan ketrampilan dan pengetahuan para pembudidaya rumput laut (Kustiari $d k k$., 2012; Kusriani dkk., 2018). Peran lembaga keuangan sangat penting untuk para pembudidaya guna meningkatkan dan mengembangkan usahanya. Peran pemerintah sangat diperlukan untuk mengembangkan potensi perairan di Negeri Sawai dengan menyediakan zonasi peruntukan wilayah yang jelas dalam menghindari potensi konflik pemanfaatan (Fadli dkk., 2017; Suhu dan Wance, 2019).

\section{Leverage of Attributes}

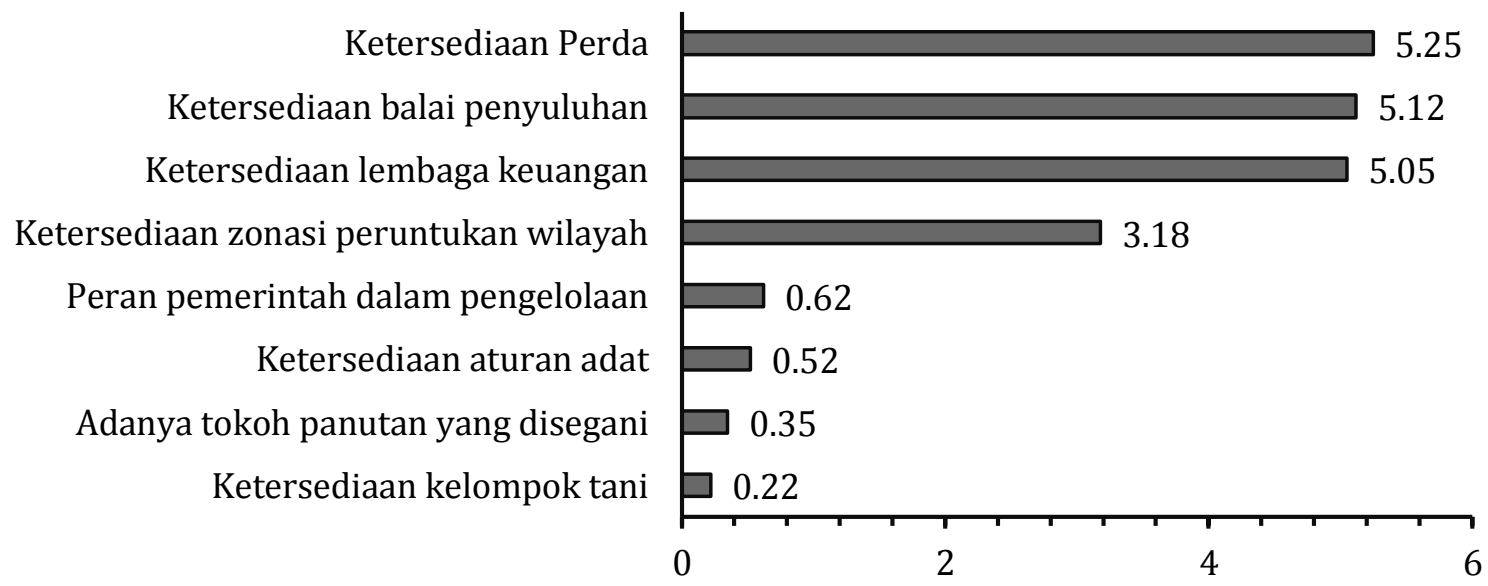

Root Mean Square Change in Ordination when Selected Attribute Removed (on Sustainability scale 0 to 100)

Gambar 5. Hasil analisis leverage dimensi kelembagaan 
Besarnya potensi budidaya rumput laut yang ditunjukan dengan besarnya nilai keberlanjutan dimensi ekologi belum didukung secara penuh oleh teknologi, sosial maupun kelembagaan yang baik sehingga belum mampu memberikan manfaat ekonomi untuk jangka panjang (Gambar 6) bagi masyarakat Negeri Sawai, hal ini dapat menjadi ancaman terhadap keberlanjutan budidaya rumput laut.

Pada diagram layang terlihat bahwa dimensi ekologi memiliki tingkat keberlanjutan yang lebih tinggi jika dibandingkan dengan dimensi lainnya. Hal ini berkaitan dengan lokasi budidaya rumput laut di perairan Negeri Sawai yang tergolong baik karena sangat terlindung sehingga mendukung pertumbuhan rumput laut. Keberlanjutan dimensi ekologi ini perlu dipertahankan dalam pengelolaanya. Dimensi ekonomi, teknologi, sosial dan kelembagaan berada dalam kategori kurang berkelanjutan, sehingga perlu ditingkatkan pengelolaannya secara serius. Keberlanjutan dimensi ekonomi dapat berkaitan dengan transfer keuntungan yang lebih banyak dimiliki oleh masyarakat lokal dan sekitar. Kegiatan budidaya rumput laut di Negeri Sawai melibatkan tenaga kerja yang berasal dari Negeri Sawai dan masyarakat sekitar. Dengan demikian, keuntungan lebih banyak dimiliki oleh masyarakat lokal dan sekitar.

Keberlanjutan dimensi teknologi dapat berkaitan dengan tingkat penguasaan teknologi budidaya rumput laut. Salah satu keunggulan dari usaha budidaya rumput laut yaitu teknologi yang digunakan sangat mudah untuk diaplikasikan kepada masyarakat pesisir. Sarana dan prasarana yang digunakan juga mudah diperoleh, oleh karena itu dengan cara meningkatkan ketrampilan dan pemahaman pembudidaya dengan teknologi yang baik maka dapat memaksimalkan potensi lahan budidaya rumput laut di Negeri Sawai.

Keberlanjutan dimensi sosial dapat disebabkan karena hampir tidak pernah terjadi konflik dalam kegiatan pemanfaatan lahan budidaya rumput laut di Negeri sawai. Kurangnya pemahaman masyarakat tentang nilai ekonomis rumput laut dan teknologi yang tepat mengakibatkan kurang berkembangnya usaha budidaya rumput laut. Kondisi dimensi sosial juga dipengaruhi oleh rendahnya pengaruh masyarakat dalam penyusunan aturan pemanfaatan dalam bidang perikanan dan budidaya. Saat ini, pemerintah belum memberikan ruang partipasi yang luas bagi masyarakat dalam hal penyusunan aturan pemanfaatan. Semakin rendah pengaruh/keterlibatan masyarakat terutama pelaku pemanfaatan sumberdaya perikanan maupun budidaya, maka cenderung menyebabkan rendahnya tanggung jawab masyarakat terhadap pelaksanaan aturan tersebut seperti kepatuhan dalam menjaga kondisi lingkungan.

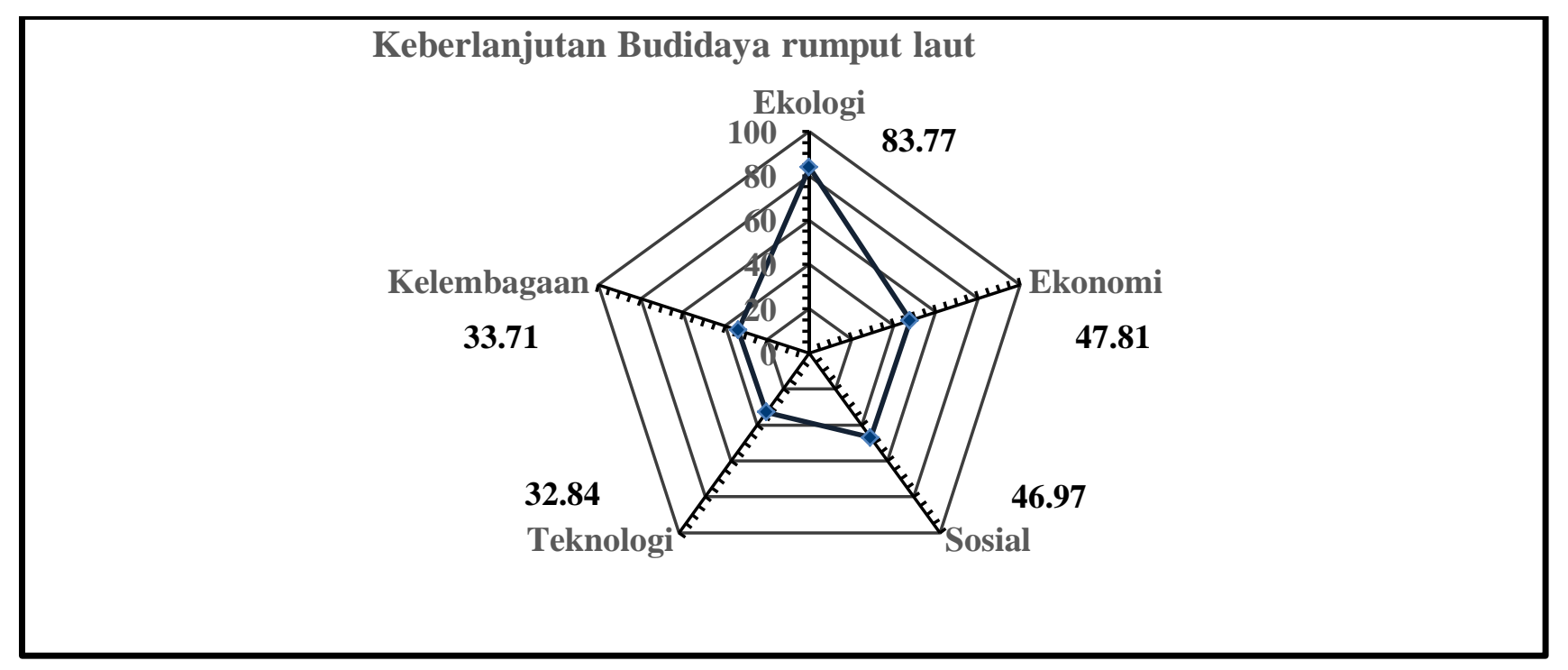

Gambar 6. Diagram layang keberlanjutan budidaya rumput laut di Negeri Sawai 
Dimensi kelembagaan merupakan dimensi yang memiliki tingkat keberlanjutan terendah jika dibandingkan dengan dimensi lainnya, sehingga perlu mendapatkan perhatian serius dalam pengelolaannya. Rendahnya tingkat keberlanjutan pada dimensi kelembagaan disebabkan karena rendahnya peran lembaga dalam pengembangan budidaya rumput laut di Negeri Sawai. Keterlibatan pemerintah diperlukan agar pengembangan budidaya rumput laut dapat berjalan dengan baik namun peran pemerintah dirasa belum maksimal.

Arahan pengelolaan merupakan suatu bagian yang penting dalam proses pengembangan budidaya rumput laut di Negeri Sawai. Berdasarkan hasil analisis yang telah diuraikan sebelumnya maka dapat direkomendasikan beberapa arahan pengelolaan antara lain: 1). Menjamin ketersediaan bibit melalui program kebun bibit. Peran pemerintah dalam hal ini Dinas Kelautan dan Perikanan dapat mengupayakan kebun bibit untuk menjaga ketersediaan bibit rumput laut yang berkualitas di Negeri Sawai. 2). Peningkatan keterampilan dan pengetahuan pembudidaya rumput laut melalui sosialisasi, penyuluhan dan pelatihan. 3). Ketersediaan dan jaminan akses pasar merupakan salah satu langkah penting dalam mengembangkan budidaya rumput laut di Negeri Sawai. 4). Penyediaan sarana pengering rumput laut. Sarana pengeringan akan menjamin kualitas rumput laut yang dihasilkan. 5). Menyediakan sarana penyimpanan rumput laut. 6). Mengembangkan industri pengolahan rumput laut. 7). Penetapan peraturan negeri tentang pengelolaan wilayah pesisir yang disertai sanksi yang tegas kepada masyarakat yang melanggar seperti larangan membuang sampah di laut. 8). Mengusahakan bantuan dan sistem permodalan melalui Program Kredit Pemberdayaan Ekonomi sehingga pembudidaya dapat meningkatkan kemandiriannya dalam berusaha dan mengembangkan usaha budidaya rumput laut.

\section{KESIMPULAN DAN SARAN}

Berdasarkan hasil penelitian dapat disimpulkan bahwa status keberlanjutan budidaya rumput laut di Negeri Sawai menunjukan bahwa dimensi ekologi tergolong berkelanjutan, sedangkan dimensi ekonomi, teknologi, sosial dan kelembagaan tergolong kurang berkelanjutan, dengan 8 arahan pengelolaan budidaya rumput laut.

Berdasarkan hasil penelitian ini maka disarankan agar budidaya rumput laut di lokasi penelitian ini perlu penelitian lanjutan mengenai dimensi ekonomi, teknologi, sosial dan kelembagaan yang tergolong kurang berkelanjutan, sehingga menjadi bahan evaluasi bagi pemerintah daerah guna pengembangan budidaya rumput laut.

\section{DAFTAR PUSTAKA}

Anggadiredja, J. T., A. Zatnika, H. Purwanto, dan S. Istini. 2006. Rumput Laut Pembudidayaan, Pengolahan dan Pemasaran Komoditas Perikanan Potensial (146 Hal). Penebar Swadaya. Jakarta.

Arthana, I. W., Pertami, N. D., Hendrawan, I. G., Wijayanto, D. B., Perwira, I. Y., Ulinuha, D. 2012. Pemetaan Potensi Kawasan Budidaya Rumput Laut di Perairan Tenggara Pulau Bali. Laporan Penelitian. Bukit Jimbaran, Indonesia: Fakultas Kelautan dan Perikanan Universitas Udayana

Damelia, D. \& E. Soesilowati. 2016. The Strategy to Improve the Competitiveness of Indonesia Seaweeds in Global Market. Jurnal Ekonomi Pembangunan 17(2): 193-204.

Dinas Kelautan dan Perikanan. 2014. Laporan Tahunan Dinas Kelautan dan Perikanan. Kabupaten Maluku Tengah.

Erbabley, N. Y. G. F. \& Kelabora, D. M. Identifikasi Bakteri Rumput Laut Kappaphycus alvarezii Berdasarkan Musim Tanam di Perairan Maluku Tenggara. Jurnal Akuatika Indonesia 3(1): 19-25.

Fadli, R. Pambudy, Harianto. 2017. Analisis Daya Saing Agribisnis Rumput Laut di Kabupaten Lombok Timur. Jurnal Agribisnis Indonesia 5(2): 89-102. E-ISSN 2579-3594.

Fauzi, A. \& Anna, S. 2002. Evaluasi Status Keberlanjutan Pembangunan Perikanan: Aplikasi Pendekatan Rapfish (Studi Kasus Perairan Pesisir DKI Jakarta). Jurnal Pesisir Dan Lautan, Volume 4, No. 3, Hal. 43-55. Pusat Kajian Sumberdaya Pesisir dan Lautan, Institute Pertanian Bogor.

Fitrian, T. 2015. Hama Penyakit (Ice-ice) pada Budidaya Rumput Laut Studi Kasus: Maluku 
Tenggara. Oseana XI (4): 1-10. ISSn 02161877.

Kamlasi, Y. 2008. Kajian Ekologis dan Biologi untuk Pengembangan Budidaya Rumput Laut (Eucheuma cottonii) di Kecamatan Kupang Barat Kabupaten Kupang Provinsi Nusa Tenggara Timur. Tesis. Sekolah Pascasarjana. Institut Pertanian Bogor. Bogor.

Kavanagh P, \& Pitcher TJ. 2004. Implementing Microsoft Excel Software For Rapfish: A Technique For The Rapid Appraisal of Fisheries Status. University of British Colombia. Fisheries Centre Research Report 12 (2) 75 p. ISSN 1198-6727.

Kusriani, Supriatna, P. Widjanarko. 2018. Budidaya Rumput Laut (Gracillaria wringin anom). Jurnal Akses Pengabdian Indonesia 3(1): 3541.

Kustiari, T., Sumardjo, M. Slamet, P. Tjitropranoto. 2012. Pengaruh Efektivitas Penyuluhan Terhadap Kompetensi Pembudidaya Rumput Laut Polikultur di Perairan Pantai Utara Pulau Jawa. Jurnal Sosek KP 7(1): 79-95.

Mandika, S., Wibowo, B. A. Pramonowibowo. 2013. Analisis Strategi Pemanfaatan Sumberdaya ikan Ditinjau dari Aspek Teknis Penangkapan di Perairan Rawapening. Journal of Fisheries Resources Utilization Management and Technology (2(3): 111-120.

Maryunus, R. P. 2018. Pengendalian Penyakit Iceice Budidaya Rumput Laut, Kappaphycus alvarezii: Korelasi Musim dan manipulasi Terbatas Lingkungan. Jurnal Kebijakan Perikanan Indonesia 10(1): 1-10. E-ISSN: 2502-6550.

Maryunus, R. P., J. Hiariey, Y. Lopulalan. 2018. Faktor Produksi dan Perkembangan Produksi Usaha Budidaya Rumput Laut Kotonii di Kabupaten Seram Bagian Barat. Jurnal Sosek KP 13(2): 179-192.

Mudeng, J. D., K. Magdalena, R. Abdul. 2015. Kondisi Lingkungan pada Lahan Budidaya Rumput Laut Kappaphycus alvarezi di Desa
Jayakarsa Kabupaten Minahasa Utara. Jurnal

Budidaya Perairan 3(1): 172-186. DOI: https://doi.org/10.35800/bdp.3.1.2015.6 953.

Radiena, M. S. Y. 2014. Pengolahan Rumput Laut (Euchema sp) Menjadi Produk Pengharum Ruangan Aromaterapi. Majalah Biam 10(1): 31-36.

Raharja, E., S. B. Prayitno, Sarjito. 2016. Pengaruh Konsentrasi Konsorsium Bakteri K7, K8 dan K9 Terhadap Status Kesehatan Rumput Laut (Euchema cottonii). Journal of Aquaculture Management and Technology 5(1): 108-115.

Risnawati, M. Kasim, Haslianti. 2018. Studi Kualitas Air Kaitanya dengan Pertumbuhan Rumput Laut (Kappaphycus alvarezii) Pada Rakit Jaring Apung Di Perairan Pantai Lakeba Kota Bau-Bau Sulawesi Tenggara. Jurnal Manajemen Sumber Daya Perairan 4(2): 155-164. E-ISSN 25034286.

Setyaningsih, H., K. Sumantadinata, N. S. Palupi. 2012. Kelayakan Usaha Budi Daya Rumput Laut Kappaphycus Alvarezii Dengan Metode Longline dan Strategi Pengembangannya di Perairan Karimunjawa. Jurnal Manajemen Pengembangan Industri Kecil Menengah 7(2): 131-142. DOI: https://doi.org/10.29244/mikm.7.2.131142.

Suhu, B. L \& M. Wance. 2019. Pemberdayaan Masyarakat Petani Rumput Laut di Kabupaten Halmahera Selatan. Jurnal of Government (Kajian Manajemen Pemerintahan dan Otonomi Daerah) 4(2): 156-172.

Sulma, S., dan Manoppo, A. 2008. Kesesuaian Fisik Perairan untuk Budidaya Rumput Laut di Perairan Bali Menggunakan Data Penginderaan Jauh. Pusat Pengembangan Pemanfaatan dan Teknologi Penginderaan Jauh LAPAN. PIT MAPIN XVII, Bandung. 10 hal. 